\title{
Eschatology and Positivism: The Critique of Phenomenology in Derrida and Foucault
}

\section{Leonard Lawlor}

In his early "What is Metaphysics?," Heidegger claims that the question expressed in the title of his essay puts the questioner-us-in question. This "putting us in question" then moves forward towards, as Heidegger says, the completion of the transformation of man, understood as subject, into existence (Dasein). ${ }^{1}$ This complete transformation, for Heidegger, as we know from the Introduction to the essay that he added in 1949, amounts to an overcoming (Uberwindung) of metaphysics understood as Platonism or as the mere reversal of Platonism (PM 363/279). At this moment, I think it is still necessary to take seriously Heidegger's attempt to overcome metaphysics. ${ }^{2}$ Heidegger had pointed the way towards the overcoming of metaphysics by calling us to think what he calls the "Auseinander" of the opening of being itself (PM 369/ 284). How are we to translate into English this German word "Auseinander"? Perhaps as the "outside of one another" or even 
as the "outside itself." No matter what, however, "Auseinander" implies that, in order to overcome metaphysics, we must have a thought of the outside. A thought of the outside would be a thought that comes from the outside which is as well a thought about the outside. This outside, it seems to me, however, is not "the opening of being," as Heidegger says, but the opening of life. The outside is a place in which life and death indefinitely delimit one another. But to move us to this place of delimitation, we must start with a critique of phenomenology.

We must start here because phenomenology has shown a remarkable resilience across the Twentieth Century. But more importantly, we must start here because phenomenology has already conceived life through its central concept of Erlebnis ("lived-experience" in English, "vécu" in French). Therefore, we can ask whether phenomenology itself has already initiated an overcoming of metaphysics. Husserl, of course, thought so. Yet, certain critiques in France dating from the 1960 's imply that lived-experience consists in a kind of insideness, which is not internal, and a kind of sameness, which is not identity - but mixture and ambiguity. If mixture and ambiguity define lived-experience, then it follows that sometimes phenomenology restores Platonism, while other times it merely reverses Platonism into its opposite. Understood in this way, as sameness and inside-ness, phenomenology does not overcome metaphysics. Phenomenology is not a thought of the outside-or, at least, this is what I would like to show here. If you heard the allusion in the phrase "the thought of the outside," you know that I am thinking of Foucault, in particular, the critique of phenomenology found in his 1966 Les Mots et les choses. ${ }^{3}$ The other critique comes from Derrida's 1967 La Voix et le pbénomène. ${ }^{4}$ In any case, what I intend to do here is reconstruct the critique of phenomenology found in Foucault and Derrida. ${ }^{5}$ I am going to start with Foucault, and in particular, with Chapter Nine of Les Mots et les choses, "Man and his Doubles." 


\section{The Analysis of Lived-Experience (vécu) is a Discourse with a Mixed Nature}

Chapter Nine of Les Mots et les choses, "Man and his Doubles," contains, of course, Foucault's critique of modern humanism. "The chapter therefore focuses on man (and not on the human being). Foucault defines man as a double; he is at once an object of knowledge and a subject that knows (MC 323/312). Man (and again not the human being) is what occupies, as Foucault says, this "ambiguous position." The entire critique of humanism unfolds, for Foucault, from this designation of man as "ambiguous," a designation which recalls, of course, Merleau-Ponty and Sartre. I shall turn to Merleau-Ponty in a moment. In any case, for Foucault, the ambiguity that defines man consists in two senses of finitude. In one sense, finitude consists in the empirical positivities, the empirical contents of "work, life, and language," which tell man that he is finite (MC 326/315). The knowledge of life, for instance, tells man that he is going to die. The other sense is that this finitude is itself fundamental. The forms of knowledge in which the very contents that tell man that he is finite are forms which are themselves finite. For instance, for man, there is no intellectual intuition. So, finitude is ambiguous between empirical content and foundational forms. For Foucault, this ambiguity of finitude results in an "obligation" to ascend "up to an analytic of finitude." Here it is necessary to hear the word "analytic" in its Kantian sense, as a "theory of the subject" (MC 330/310). For Foucault, this would be an analytic "where the being of man will be able to found, in their positivity, all the forms that indicate to him that he is not infinite" (MC 326/315, my emphasis). This analytic would be the discourse of phenomenology.

The discourse of phenomenology would aim at, according to Foucault, a truth that would be neither empirical con- 
tent nor transcendental form, while trying to keep the empirical and transcendental separated. This is an important qualification- "while trying to keep the empirical and transcendental separated"--since what is at issue is here whether phenomenology can maintain the separation between the empirical and the transcendental. In any case, according to Foucault, phenomenology would be an analytic of man as a subject in this precise sense: man as subject, "that is, as the place of empirical knowledge but led back as close as possible to what makes empirical knowledge possible, and as the pure form that is immediately present to these contents." Man as subject therefore would be the third and intermediary term in which empiricity and transcendentality would have their roots. According to Foucault, this third and intermediary term has been designated by "le vécu." "Le vécu" responds to the "obligation" to analyze finitude, that is, to the obligation to have a theory of the subject. Here is Foucault's definition of "le vécu": "lived-experience, in fact, is at once the space where all empirical content is given to experience; it is also the originary form that makes them in general possible." We can now see the problem with "le vécu," and indeed, with "man." "Le vécu" must be concrete enough in order to be able to apply to it a descriptive language; yet it must be enough removed from positivity so that it can provide the foundations for empirical positivity. 'The discourse of vécu tries to make the empirical hold for the transcendental: the empirical is the transcendental and the transcendental is the empirical, or, the content is the form and the form is the content. Lived-experience therefore is a mixture. And thus Foucault says that "the analysis of lived-experience [vécu] is a discourse with a mixed nature: it is addressed to a specific but ambiguous layer" (MC 332/321). This analytic "mixes" the transcendental and the empirical together. Therefore, what we have seen so far is that the concept of lived-experience, as Foucault understands it - and this 
is also how Derrida understands it, as we shall see in a moment-consists not in an identity of empirical content and foundational form but in a mixture or ambiguity between these two. Here, however, one could plausibly wonder whether such a definition can be found in phenomenology. So, let us turn now to Husserl and then to Merleau-Ponty to confirm this definition.

\section{Lived-Experience (das Erlebnis, le vécu) in General}

We have been discussing Erlebnis; so, let us turn to Husserl's classical definition of Erlebnis in Ideas $I$, in section 36, which is entitled "Intentional Lived Experiences. Lived Experiences in General." Here, in order to distinguish what he is doing from psychology, Husserl says, "Rather [than a discourse of real psychological facts; the word "real" is, of course, important,] the discourse here and throughout is about purely phenomenological lived-experiences, that is, their essences, and on that basis, what is 'a priori' enclosed in [in beschlossen] their essences with unconditional necessity" (HUA III:1, p. 80). ${ }^{8}$ As I just said, that Husserl calls psychological facts "real" is important, because all purely phenomenological lived-experiences are "reelle." What Husserl calls intentional lived experiences, thoughts in the broadest sense, are reelle, which means that thoughts are internal. Yet, intentional lived experience also contains "the fundamental characteristic of intentionality," the property of being consciousness of something. This "of something"--the fundamental characteristic of intentionality-means that lived-experience is related to an outside; something comes from the outside into lived-experience. But, Husserl says, "within the concrete unity of an intentional lived experience," there are reelle moments, which do not have the fundamental characteristic of inten- 
tionality; these reelle moments are the data of sensation. Here, Husserl has discovered something non-intentional and therefore passive at the very heart of lived-experience, something that comes from the outside, and yet he has designated these moments as "reelle," and thereby as "enclosed in" "das Erlebnis überhaupt." By means of this "überhaupt" and this "in beschlossen," we can conclude already that Erlebnis, in this classical formulation, consists in a sameness, which is not identity, and an inside-ness which is not simply internal; in a word, Erlebnis "in general" consists in a mixture.

To demonstrate this sameness and inside-ness again, I would also like to look at another Husserl text: the final version of Husserl's 1927 Encyclopedia Britannica entry on "Phenomenology." As is well-known, this text introduces phenomenology through phenomenological psychology. Phenomenological psychology, Husserl says here, has the task of investigating the totality of lived experience. But, more importantly, phenomenological psychology, according to Husserl, is an easier way to enter into the transcendental problem that occurred historically with Descartes, that is, that all of reality, and finally the whole world, are for us in existence and in existence in a certain way only as the representational content of our own representations. Thus everything real has to be related back to us. But this "us" cannot be the psyche, according to Husserl, because the psyche is defined by the mundane sense of being as Vorbandenheit, presence, or, more literally, presence-at-hand. To use a mundane being-whose ontological sense is Vorhandenbeit_- to account for the reality of the world - whose ontological sense is also Vorbandenbeit-is circular, and this circularity defines psychologism. ${ }^{9}$ In contrast to psychologism, phenomenology claims, according to Husserl, that there is a parallelism between psychological subjectivity and transcendental subjectivity and that this parallelism involves a deceptive appearance (Schein) of "transcenden- 
tal duplication." It is important here, it seems to me, that, while Husserl recognizes that there is some sort of difference between the transcendental and the psychological or the empirical, he does not, we might say, partition off the transcendental from the psychological or empirical. Instead, he says that transcendental subjectivity is defined by Vorbandenbeit too, but "not in the same sense" (nicht im selben Sinn vorhanden ist)..$^{10}$ Indeed, Husserl thinks that by saying "not in the same sense," he has eliminated the deceptive appearance and makes the parallelism understandable. This is what he says, "the parallelism of the transcendental and the psychological spheres of experience has become comprehensible... as a kind of identity of the interpenetration [Ineinander] of ontological senses."11 This "kind of identity," he also describes as "ambiguity" (Zweideutigkeit). Here Husserl thinks the "Ineinander," literally, one in the other, but not, we might say, the "Auseinander," literally, one outside of the other. Nevertheless, this "Zweideutigkeit" and "Ineinander" should make us think of Merleau-Ponty. So I would like to turn now to Merleau-Ponty, and in particular, to his Phenomenology of Perception. ${ }^{12}$

On the very first page of the Phenomenology of Perception, Merleau-Ponty speaks of vécu, and, throughout the Phenomenology the word modifies the term "monde," "world." For example, in the chapter called "The Phenomenal Field," MerleauPonty says that "the first philosophical act therefore would be that of returning to the lived-world on this side of the objective world" (PhP 69/57). Yet, he uses the word as a noun-_"le vécu"-only twice. The first time occurs in the chapter called "Space"; here he says "lived-experience [le vécu] is really lived by me..., but I can live more things that I can think of [plus de choses que je m'en représente]. What is only lived is ambivalent' (PhP 343/296; my emphasis). For Merleau-Ponty, ambivalence is the crucial characteristic of vécu. And this characteristic guides his analysis of intersubjectivity in the Pbenomenology of 
Perception, which is where he uses "le vécu" for the second time, in the chapter called "Others and the Human World." Here "le vécu" is defined by self-givenness ( $\mathrm{PhP} 411 / 358)$; but, this self-givenness is also given ( $\mathrm{PhP} 413 / 360)$. In other words, the active is also passive. In this formula we can see the importance of the positive affirmation in the "is." This positive affirmation is the heart of ambivalence. Now, these two uses of "le vécu" in the Phenomenology of Perception depend of course on Merleau-Ponty's appropriation of Husserl's concept of Fundierung. In the chapter called "The Cogito," Merleau-Ponty speaks of the relation between founding (le fondant) and founded (le fonde) as one that is "equivocal" (équivoque), since "every truth of fact is a truth of reason, every truth of reason is a truth of fact" (PhP 451/394; my emphasis). ${ }^{13}$ MerleauPonty also says that the relation of matter and form is a relation of Fundierung: "The form integrates the content to the point that it appears to end up being a simple mode of the form ... but reciprocally ... the content remains as a radical contingency, as the first establishment or the foundation of knowledge and action... It is this dialectic of form and content that we have to restore" (PhP 147-48/127). We can now summarize what we see in Merleau-Ponty's concept of "le vécu." For Merleau-Ponty, "le vécu” is ambivalent or equivocal-it is, we could say, a mixture, un mélange--because the content of experience, "le sol," as Merleau-Ponty also says, becomes, is integrated into, the form of expression. Phenomenological lived experience therefore is not defined by identity, but by sameness and mixture of form and content, or of empirical and transcendental.

\section{"Un Ecart infime, mais invincible"}

Both Husserl and the early Merleau-Ponty conceive Erlebnis as mixture and ambiguity because both want to over- 


\section{LEONARD LAWLOR}

come the duality of subject and object, or even the duality of what Heidegger calls the ontological difference. In other words, phenomenology is an attempt to overcome Platonism or Cartesianism (dualisms) by mixing together content and form. In both Foucault and Derrida, we find statements that assert that the phenomenological concept of Erlebnis mixes in this way. First we have Foucault's statement in Chapter Seven of Les Mots et les choses, which is called "The Limits of Representation." Foucault says:

Undoubtedly, it is not possible to give empirical contents transcendental value, or to move them onto the side of a constituting subjectivity, without giving rise, at least silently, to an anthropology, that is, to a mode of thought in which the in principle limits of knowledge [connaissance] are at the same time [en même temps] the concrete forms of existence, precisely as they are given in that same empirical knowledge [savoir]. (MC 261/248, my emphasis)

Even if phenomenology is transcendental, Foucault is saying, it still falls prey to a "silent anthropology." It takes $m y$ present or our present experiences, which are content, as foundational forms. In other words, on the basis of the empirical contents given to me, or, better, to $u s$, phenomenology tries to determine the form of that empirical content. While trying to keep them separate, phenomenology makes the transcendental and the empirical the same. It confuses them (MC 352/341). Now, in the Introduction to La Voix et le pbénomène, Derrida makes a very similar statement, but he adds something that helps us see the principle of the critique:

Presence has always been and will always be, to infinity, the form in which-we can say this apodictically-the infinite diversity of content will be produced. The opposition-which 


\section{ESCHA'IOLOGY AND POSI'ITVISM}

inaugurates metaphysics-between form and matter finds in the concrete ideality of the living present its ultimate and radical justification. (VP 5/6)

When Derrida says here that the opposition between form and content finds its ultimate and radical justification, he means that content, the root of empirical positivity, and form, the finality of transcendental foundation, are mixed together in the living present at the same time. Indeed, in both quotes, we see that the mixture of subject and object in lived-experience depends on a temporal sameness: "at the same time" or "simultaneity," "en même temps" or "à la fois." This dependence on temporal sameness tells us already that a critique of the concept of lived-experience will come from a kind of spatial thinking and from a re-institution of dualisms.

Derrida's critique can be seen most clearly in chapter six of La Voix et le phénomène, entitled "The Voice that Keeps Silent." As is well-known, Derrida's critique centers on the concept of presence. So here is the definition of presence that Derrida provides in Chapter Six:

presence [is] simultaneously [à la fois]...the beingbefore of the object, available for a look and...proximity to self in interiority. The "pre" of the present object now-before is an against [contre] (Gegenwart, Gegenstand) simultaneously [a la fois] in the sense of the wholly against [toutcontre] of proximity and in the sense of the encounter [l'encontre] of the op-posed. (VP 8384/75; Derrida's italics)

Presence, as Derrida understands it, is à la fois close by and proximate, and à la fois away and distant. In other words, it must be "at the same time" self-presence and presence, the object as repeatable to infinity and the presence of the constituting acts to themselves. For Derrida, this ambiguity between presence of an object and self-presence of a subject is found 
in the voice of interior monologue, in other words, hearing oneself speak. The primary characteristic of this "absolutely unique type of auto-affection" (VP 88/78) is temporality. When I speak to myself silently, the sound is iterated across moments. This temporal iteration is why, as Derrida explains, sound is the most ideal of all signs (VP 86/77). Thus, in hearing-oneself-speak, one still exteriorizes one's thoughts or "meaning-intention" or acts of repetition in the iterated and iterable phonemes. This exteriorization-expression-seems to imply that we have now moved from time to space. But, since the sound is heard by the subject during the time he is speaking, the voice is in absolute proximity to its speaker, "within the absolute proximity of its present" (VP 85/76), “absolutely close to me" (VP 87/77). The subject lets himself be affected by the phoneme (that is, he hears his own sounds, his own voice, "la voix propre") without any detour through exteriority or through the world, or, as Derrida says, without any detour through "the non-proper in general" (VP 88/78). Hearing-oneself-speak is "lived [vécue] as absolutely pure auto-affection" (VP 89/79). What makes it be a pure auto-affection, according to Derrida, is that it is "a self-proximity which would be nothing other than the absolute reduction of space in general" (VP 89/79). Yet-and this is a crucial "yet"- there is a double here between hearing and speaking. As Derrida says, this pure auto-affection, which is the very root of transcendental Erlebnis, supposes that "a pure difference... divides the presence to oneself" (VP 92/82). This difference divides the "auto." As Derrida says, "It produces the same as the self-relation within the difference with oneself, the same as the non-identical" (VP 92/82). Being nonidentical, auto-affection is ambiguous. We must understand the non-identity, however, in the following way: when I hear myself speak, the hearing is a repetition of the speaking that has already disappeared; re-presentation (Vergegenwärtigung) has 


\section{ESCHA'I'OLOGY AND POSI'ITVISM}

intervened, and that intervention means, in a word, space. As Derrida says, "the 'outside' insinuates itself in the movement by which the inside of non-space, what has the name of 'time,' appears to itself, constitutes itself, 'presents' itself" (VP 96/ 86). Within time, there is a fundamental "spacing" (espacement) (VP 96/86). ${ }^{14}$ Derrida also calls this spacing "un écart" within "le vécu" (VP 77/69). On the basis of Derrida's use of the word "écart," we can rejoin Foucault.

In Les.Mots et les choses, Foucault says that all of the doubles in which man consists are based on "un écart infime, mais invincible"; the English translation says, a "hiatus, miniscule and yet invincible" (MC 351/340). Here we can dissociate an ambiguity in the word "infime." This "écart" is "infime," that is, miniscule; insofar as it is miniscule, the "écarl" closes and relates "in the manner of "a mixed nature." But, this "écarl" is also "infime," in the sense of infinitesimal, infinitely divisible, and thus a great distance that separates and keeps open. It seems to me that this écart infime sets up all the problems that are ours. In fact, I think it is impossible to over-estimate the importance of chapter nine in Les Mots et les choses, "Man and his Doubles." Foucault says here, after mentioning this miniscule hiatus, that:

[In contrast to classical thought, in which time founds space], in modern thought, what is revealed at the foundation of the history of things and of the historicity proper to man is the distance hollowing out the Same, it is the hiatus [écart] that disperses the Same and gathers it back at the two edges of itself. It is this profound spatiality that allows modern thought still to think time-to know it as succession, to promise it as completion, origin or return. (MC 351/340) 
It seems to me, if I may extend the analysis a bit, that we must see this "profound spatiality" working, as well, in Deleuze's critique of phenomenology found both in his 1968 Difference and Repetition ${ }^{15}$ and in his 1969 Logic of Sense. ${ }^{16}$ For Deleuze, the phenomenological concept of Urdoxa, which one finds in both Husserl and in Merleau-Ponty, is not originary, since it is always "copied off" - "décalque" - the doxa or common sense. ${ }^{17}$ This "copying off" means that the Urdoxa is mixed with or the same as the doxa; they resemble one another and are not differentiated. The phenomenological concept of Urdoxa has violated therefore the most basic principle of Deleuze's thought, perhaps the most basic principle of thought itself: "The foundation can never resemble the founded." Deleuze continues, "It is not enough to say about the foundation that it is another history - it is also another geography, without being another world."18 For Deleuze, the earth is a profound spatiality, consisting in "un écart infime, mais invincible."

\section{Conclusion: Memory and Life}

The critique of phenomenology found in Foucault and Derrida, as well as in Deleuze, is based in this miniscule hiatus. Despite the fact that all three--Derrida, Deleuze, and Foucault-share the same critique, there is a difference between them. To conclude, I am going to outline the difference between Derrida and Foucault. For both, the critique of phenomenological lived-experience is a critique of auto-affection. The critique depends entirely on one necessary possibility: wherever there is sensing, it must be possible for there to be a surface, and, wherever there is a surface, it must be possible for there to be space. This necessary possibility implies that auto-affection, being alone and therefore close to oneself and unified with oneself, is always already virtually double, distant from oneself and divided. But-and this is an 


\section{ESCHA'I'OLOGY AND POSI'ITVISM}

important "but," as we shall see in a moment--what divides the "auto," spacing it and making it double in Derrida is mediation, Vergegenwärtigung. Derrida always conceives the "écart infime" through Vergegenwärtigung, re-presentation. In Derrida, re-presentation contaminates presentation; mediation, in other words, contaminates the immediate, but contamination is still mediation. Thus, understood as mediation, contamination promises unity, even though it cannot, by necessity, ever keep this promise. The other is always already close by and coming, without ever arriving. Without ever being able to arrive, the one who is going to keep the promise is to come in person (in the flesh, Leiblich). Therefore, we must characterize Derrida's critique of phenomenology (as he himself has done) as an eschatological critique. It is a critique based in a promised unity that demands to be done over again and again. ${ }^{19}$

Like that of Derrida, Foucault's critique too depends entirely on one necessary possibility: wherever these is sensing, it must be possible for there to be a surface, and, wherever there is a surface, it must be possible for there to be space. This necessary possibility implies that auto-affection, being alone and therefore close to oneself and unified with oneself, is always already virtually double, distant from oneself and divided. But_-and this is where we see the difference from Derrida--what divides the auto, spacing it and making it double in Foucault is a battle. ${ }^{20}$ Foucault conceives the "écart infime" as a battle. The opponents in the battle are words and things, or hearing and seeing. The battle consists in attacks and crossings across the surface (entrecroisements), but these attacks do not form a unity. No unity is ever promised in the battle. Politics, which looks to be peace, as Foucault pointed out in Surveiller et punir, is war being fought with other means. For Foucault, the audio-visual battle is an immediate relation. There is no mediation because the opponents are can never be mixed together, or, we might say, can never contaminate one another. 
Instead, the opponents are posited as such; there is always the opposition of resistance. Therefore, we must characterize Foucault's critique of phenomenology (as he himself has done) as a positivistic critique. ${ }^{21}$ It is a critique based in a duality without negation and thus it is entirely positive. ${ }^{22}$

What are we to make of the difference in their critiques? We must return once more to Chapter Nine of Les Mots et les choses, "Man and his Doubles." Here, Foucault had laid out a kind of genealogy of phenomenology. At the beginning of the nineteenth century, he tells us, there was a dissociation in the double sense of finitude, between empirical content and foundational forms of knowledge. This dissociation was Kant's thought. The dissociation, however, led to what Foucault calls a transcendental aesthetics (the empirical content) and a transcendental dialectic (the foundational forms). The transcendental aesthetics became positivism; the transcendental dialectic became eschatology. During the nineteenth century and at the beginning of the twentieth century, this dissociation between positivism and eschatology came to be associated in two ways: Marxism and phenomenology. We can see the association in Marxism insofar as Marxism claimed to give the positive truth of man in conditions of labor and at the same time promised a revolutionary utopia. We can see this association in phenomenology insofar as phenomenology speaks of the content of Erlebnis, which can be positively described as the truth, and at the same time of the fulfillment of a meaning-intention, in other words, the promise of fulfilled truth. For Foucault, this association leads to the ambiguity that defines both Marxism and phenomenology. Now it seems to me that, in their similar but different critiques of phenomenology, Foucault and Derrida have once again dissociated positivism and eschatology. The association that phenomenology and Marxism made has become unraveled. The doubles that came to be the ambiguity of Husserl's thought, positiv- 
ism and eschatology, have now themselves become dissociated into the thought of Foucault and Derrida. On the one hand, we have Derrida's messianism, which leaps back to the eschatology of the nineteenth century. On the other hand, we have Foucault's "fortunate positivism" (un positivisme beureux), ${ }^{23}$ which obviously leaps back to the positivism of the nineteenth century. Foucault and Derrida have dissociated immanence and transcendence, faith and knowledge, and, we might even say, the heart and the brain. Both the brain and the heart are complicated spaces; we might even appropriate Heidegger's term “Auseinander" in order to conceive them. Yet, without the heart, one could not speak of life; and without the brain one could not speak of memory. Now we can see what to make of the difference between the critiques of phenom-enology that we find in Foucault and Derrida. This is our task. We must continue the overcoming of metaphysics by trying to find a new way of associating the heart and the brain. In other words, is it possible for us to find a new distribution, a new "partage," as either Derrida or Foucault would say, between the double of the heart and the brain? Perhaps this new partitioning can be found only under the heading of "memory and life."24

University of Memphis 


\section{Notes}

${ }^{1}$ Martin Heidegger, "Was ist Metaphysik?" in Wegmarken (Frankfurt am Main: Victorio Klostermann, 1967), 112. English translation: "What is Metaphysics?" in Patbmarks, trans. David Farrell Krell, ed. William McNeill (New York: Cambridge University Press, 1998), 89. Hereafter all essays in Pathmarks will be cited as PM with reference first to the German, then to the English translation.

${ }^{2}$ I have written two companion essays to "Eschatology and Positivism": "Un Ecart Infime: The Critique of the Concept of Lived-Experience (vécu) in Foucault," which is forthcoming in Research in Phenomenology; and Leonard Lawlor, "Verendlichung (Finitization): The Overcoming of Metaphysics with Life," which at this moment is unpublished. All three essays are contributions to two book projects in progress: Towards the Outside: Continental Pbilosopby before 1960, and Memory and Life: an Archeology of the Experience of Thought. Concerning the overcoming of metaphysics in Heidegger, I think that what Heidegger says, late in his career in 1964, in "Time and Being," must not mislead us. Although Heidegger seems to repudiate the intention of overcoming metaphysics, he endorses a thinking that overcomes the obstacles that tend to make a saying of being, without regard for metaphysics, inadequate. More importantly, when he speaks of leaving metaphysics alone, he uses the verb "überlassen," which also suggests a kind of super-engagement with metaphysics. See Martin Heidegger, Zur Sache des Denkens (Tübingen: Niemeyer, 1969), 25. English translation: On Time and Being, trans. Joan Stambaugh $(\mathrm{New}$ York: Harper Colophon, 1972), 24

${ }^{3}$ Michel Foucault, Les Mots et les choses (Paris: Gallimard, 1966). English translation: The Order of Things, trans. anonymous (New York: Random House, 1970). Hereafter referred to as $\mathrm{MC}$, with reference first to the French, then to the En- 


\section{ESCHA'I'OLOGY AND POSI'ITVISM}

glish translation. This project would be complete, it seems, only by a reading of Merleau-Ponty's 'L'Homme et l'adversité," in Signes (Paris: Gallimard, 1960), 299 and 306. English translation: Signs, trans. Richard C. McCleary (Evanston: Northwestern University Press, 1964), 235 and 241. I intend to pursue this question of the mélange in Merleau-Ponty in another book project: Merleau-Ponty and the Political.

${ }^{4}$ Jacques Derrida, La Voix et le phénomène (Paris: Presses Universitaires de France, 1967). English translation: Speech and Phenomena, trans. David B. Allison (Evanston, IL: Northwestern University Press, 1973). Hereafter cited as VP with reference first to the French, then to the English translation. I will use the French titles of La Voix et le pbénomène and Les Mots et les choses since the English translations are somewhat misleading.

${ }^{5}$ One finds a similar critique of the concept of Erlebnis in Hans-Georg Gadamer's Wabrheit und Metbode (Tübingen: Mohr, 1975). English translation: Truth and Method, 2d rev. ed., trans. Joel Weinsheimer and Donald G. Marshall (New York: Continuum, 1989). Gadamer claims that the concept of Erlebnis consists in the immediacy of self-consciousness and in an immediacy that yields a content (das Erlebte). His critique is that Erlebnis is unity and interiority, whereas life itself is self-diremption. Here he takes his inspiration from Hegel, "the speculative import of the concept of life" (Wabrheit und Methode, 237; Truth and Method, 250-51). Thus, because of the idea of self-diremption, Gadamer stresses the idea of judgment (Urteil), which literally means "original partitioning." Nevertheless, despite Gadamer's emphasis on Ur-teil, we think with Foucault that life is not expressed in a judgment, which still relies on unity or synthesis, but in the infinitive of a verb which can be infinitely divided without unity. It is the expression of the indefinite, a universal singularity. On this idea of the verb, see Gilles Deleuze, Logique du sens (Paris: Minuit, 
1969), 11. English translation: Logic of Sense, trans. Mark Lester, with Charles Stivale, ed. Constantin V. Boundas (New York: Columbia University Press, 1990), 3. See also Foucault's review of Deleuze's Logique du sens and Différence et répétition, "Theatrum Philosophicum," in Dits et écrits I, 1954-1975 (Paris: Gallimard, 2001), 950-51. English translation: Michel Foucault, Language, Counter-Memory, Practice, trans. and ed. Donald F. Bouchard (New York: Cornell University Press, 1977), 17375. If there is a concept in Foucault, it would be an infinitive, like "représenter," "classer," "parler," "échanger," or "surveiller et punir," or finally, "penser." It is important to recall that Deleuze says that a statement (un énoncé) - -and in Foucault a statement is the true equivalent to the concept--is a "curve" (un courbe). See Gilles Deleuze, Foucault (Paris: Minuit, 1986), 87. English translation: Foucault, trans. Sean Hand (Minneapolis: University of Minnesota Press, 1988), 80.

"See Michel Foucault, "Vie: experience et vie," in Dits et écrit, IV, 763-776. English translation: "Life: Experience and Science," trans. Robert Hurley, in Essential Works of Michel Foucault: Aesthetics, Method, and Epistemology, vol. 2, ed. James D. Faubion (New York: The New Press, 1998), 465-478.

${ }^{7}$ Edmund Husserl, Husserliana (hereafter Hua) III.1: Ideen zu einer reinen Pbänomenologie und phanomenologischen Pbilosophie: Erstes Buch, ed. Karl Schuhmann (The Hague: Martinus Nijhoff, 1976). English translation: Ideas Pertaining to a Pure Phenomenology and to a Phenomenological Philosophy, trans. F. Kersten (The Hague: Martinus Nijhoff, 1982). See also Edmund Husserl, Idées directrices pour une pbénoménologie, trans. Paul Ricour (Paris: Gallimard, 1950).

${ }^{8}$ Here I am relying on a later revision of the passage that Husserl made: “copy D.” See Kersten's English translation, p. 73.

${ }^{2}$ This solution to the transcendental problem, a solution which defines "psychologism," is circular because it takes some- 
thing existing in the world, the psyche, which has the ontological sense of something existing in the world, Vorbandenbeit, and tries to make this something present account for all things present.

${ }^{10}$ Edmund Husserl, Hua IX: Phänomenologische Psychologie (The Hague: Martinus Nijhoff, 1962), 292. English translation: in The Essential Husserl, trans. Richard E. Palmer, ed. Donn Welton (Bloomington: Indiana University Press, 1999), 331.

${ }^{11}$ Hua IX, p. 294; The Essential Husserl, 332.

12 Maurice Merleau-Ponty, Phénoménologie de la perception (Paris: Gallimard, 1945). English translation: Phenomenology of Perception, trans. Colin Smith, rev. Forrest Williams (New Jersey: The Humanities Press, 1981). Hereafter PhP, with reference first to the French, then to the English.

${ }^{13}$ Thomas Busch also cites this passage in his "Maurice Merleau-Ponty: Alterity and Dialogue" in Circulating Being: Essays in Late Existentialism (New York: Fordham University Press, 1999), 83. Busch's interpretation of Merleau-Ponty's concept of ambiguity and equivocity is based on the idea of dialogue, an idea very different from a battle.

${ }^{14}$ Spacing implies what Derrida calls "archi-writing" and thus vision: "when I see myself writing and when I signify by gestures, the proximity of hearing myself speak is broken" (VP 90/80). Thus here we could speak of a story of the eye, which would allow for a further comparison with Foucault.

${ }^{15}$ Gilles Deleuze, Différence et répétition (Paris: Presses Universitaires de France, 1968), 179. English translation: Difference and Repetition, trans. Paul Patton (New York: Columbia University Press, 1994), 137.

${ }^{16}$ Gilles Deleuze, Logique du sens (Paris: Minuit, 1969), 119 and 124; English translation: Logic of Sense, trans. Mark Lester, with Charles Stivale, ed. Constantin Boundas (New York: Columbia University Press, 1990), 97 and 102. 
${ }^{17}$ See Deleuze, Différence et répétition, 177; Difference and Repetition, p. 135; also Deleuze, Logique du sens, 54; Logic of Sense, 39.

${ }^{18}$ Deleuze, Logique du sens, 120; Logic of Sense, 99, my emphasis.

${ }^{19}$ I have coined a word for this idea of "a promise that demands to be done over again and again": "refinition." See the Preface to my Derrida and Husserl: The Basic Problem of Phenomenology (Bloomington: Indiana University Press, 2002), as well as Thinking Through French Philosophy: The Being of the Question (Bloomington: Indiana University Press, 2003).

20 'This description is based largely on Michel Foucault, Ceci n'est pas une pipe (Paris: Fata Morgana, 1973). English translation: This is Not a Pipe, trans. James Harnes (Berkeley: University of California Press, 1983). See also Gilles Deleuze, Foucault, 119/112.

${ }^{21}$ I am extrapolating from what Foucault has said in his L'ordre du discours (Paris: Gallimard, 1971), p. 72; English translation: "The Discourse on Language," appendix to The Archeology of Knowledge, trans. A. M. Sheridan (New York: Pantheon, 1972), 234.

${ }^{22}$ If we were to pursue further this difference between Foucault and Derrida, we would have to investigate the concept of multiplicity.

${ }^{23}$ Foucault, L'Ordre du discours, 72; "The Discourse on Language," 234. 